\begin{tabular}{ll}
\hline Jurnal Scripta Teologi dan Pelayanan Kontekstual & \\
ISSN 2086-5368 (Print) & STT Ebenhaezer \\
ISSN & Tanjung Enim \\
Http://ejournal.stte.ac.id & STTE \\
Vol.3, No.2, pp. $172-183,2018$ &
\end{tabular}

\title{
Pastoral Konseling Menurut Yehezkiel 34:16 Sebagai Upaya pemulihan Mental
}

\author{
Yenny Anita Pattinama \\ STT Ebenhaezer Tanjung Enim, yennyanitapattinam1980@gmail.com
}

\section{INFO ARTIKEL}

Sejarah Artikel:

Diterima : 04 Nov 2018

Direvisi : 09 Nov 2018

Disetujui: 18 Nov 2018

Dipublikasi: $28 \mathrm{Nov}$

2018

Kata Kunci:

Pastoral, Konseling,

Yehezkiel, Pemulihan,

Mental.

Keywords:

keyword one, keyword two, keyword three.

\section{ABSTRAK}

Pada hakikatnya, setiap manusia dalam kehidupannya dimanapun ia berada pasti memiliki masalah dan pergumulan. Pastoral konseling mengajarkan mereka untuk mampu berdamai dengan Allah, diri sendiri, dan juga orang lain. Dengan melakukan pelayanan pastoral konseling juga dapat menyadarkan mahasiswa-mahasiswi yang bermasalah akan pelanggaran yang dilakukan, kemudian mengakui setiap perbuatannya yang salah dihadapan Tuhan, dan dapat menerima pengampunan dan memulai suatu kehidupan yang baru. Dengan demikian seorang konselor dapat menolong setiap konseli untuk mengalami pemulihan mental dan memahami tindakannya salah yang pernah diperbuatnya serta melakukan langkah-langkah untuk menata kehidupannya menjadi lebih baik.

\section{ABSTRACT}

In essence, every human being in his life wherever he is must have problems and struggles. Pastoral counseling teaches them to be able to make peace with God, themselves, and also others. Conducting pastoral counseling services can also awaken students who have problems with violations committed, then acknowledge any wrongdoing before God, and can receive forgiveness and start a new life. Thus a counselor can help each counselee to experience mental recovery and understand the wrong actions he had ever done and take steps to organize his life for the better.

\section{Pendahuluan}

Manusia adalah makhluk yang Tuhan ciptakan pada hari keenam. Dalam Kejadian 1:31 dicatat bahwa setelah Allah menciptakan manusia, Allah menilai itu semua amat baik. Penciptaan memberikan kepada manusia tempat mulia dalam alam semesta. Mulia menunjukkan penyataan diri, sifat dan kehadiran Allah kepada manusia. Ichwei G. Indra mengatakan: Manusia pada hakikatnya diciptakan menurut "gambar dan rupa Allah" (Kej. 1:26-27). Hal ini memberikan arti bahwa manusia memiliki kesamaan dengan Allah. Dengan demikian, Ichwei G. Indra mengatakan bahwa:

Makna "gambar dan rupa Allah" di dalam diri manusia adalah: (1) kemampuan manusia untuk bersekutu dengan Allah (Kej. 1:28; 2:16-19); (2) 
kemampuan manusia untuk memahami dan melaksanakan kehendak Allah dalam penciptaan (Kej. 1:28).

Manusia ditempatkan Tuhan di taman Eden. Semua keperluan jasmani manusia dipenuhi oleh Tuhan (Kej. 2:9). Tuhan Allah hanya memberikan satu peraturan yang membatasi kebebasan kuasa manusia untuk mengatur hidupnya, yaitu: "tetapi pohon pengetahuan tentang yang baik dan yang jahat, jangan kau makan buahnya, sebab pada hari engkau memakannya, pastilah engkau mati” (Kej. 2:17). Namun manusia itupun tergoda memakan buah tersebut, sehingga mereka harus merasakan hukuman dari Allah.

Ketika pertama kali manusia jatuh ke dalam dosa, maka tindakan pertama Allah adalah mencari dan memanggil manusia yang bersembunyi dari hadapan Tuhan (Kej.2:8-9). Allah tahu bahwa manusia yang diciptanya itu telah melanggar aturan yang sudah ditetapkan oleh Allah. Tetapi Allah tidak membiarkan ciptaan-Nya itu larut dalam dosa karena Allah 'sadar' bahwa setiap orang membutuhkan pemeliharaan dan perawatan yang semakin besar ketika melalui masa sulit.

Tindakan Allah mencari manusia mengidentifikasikan bahwa Allah adalah pelopor penggembalaan dan Tuhan sendiri sebagai gembala. Hal inilah yang disadari oleh Daud dalam kehidupannya yang penuh tantangan. Tuhan sebagai gembala yang baik bagi Daud menyediakan yang terbaik baginya baik dari segi jasmani maupun spiritual. Dari segi jasmani "la membaringkan aku di padang yang berumput hijau, la membimbing aku ke air yang tenang", dari segi spiritual "la menyegarkan jiwaku”. Pemeliharaan Allah sebagai gembala yang baik menyegarkan jiwa yang tertekan karena dosa dengan pengampunan-Nya sekalipun dosa itu harus mendapat konsekuensi, namun sebelumnya Allah membina orang yang melakukan dosa kepada kebenaran.

Dalam kitab Kejadian, dosa mempengaruhi hubungan nenek moyang pertama dengan Allah, mempengaruhi sifat mereka, mempengaruhi tubuh mereka dan alam di sekitar mereka. Sebelum kejatuhan manusia, Allah dan manusia bersekutu satu sama lain; setelah kejatuhan, persekutuan itu putus. Mereka bukannya mencari persekutuan dengan Allah malah berusaha lari menjauhi Allah. Hati nurani mereka yang merasa tertuduh membuat mereka tidak dapat merasa tenang, sehingga mereka mulai berusaha mengalihkan tanggungjawab.

Pelanggaran yang Adam dan Hawa lakukan membuat mereka malu (Kej.3:7). Tidak senang dengan diri sendiri, sebagaimana diri sendiri adanya, dan karena itu tidak senang kalau dilihat orang lain. Ketika Allah mengatakan dalam Kejadian 2:17 bahwa akibat ketidaktaatan manusia adalah "pasti akan mati". Allah berfirman kepada Adam, "Sebab engkau debu dan engkau akan kembali menjadi debu" (Kej. 3:19). Kata-kata Paulus, "sama seperti semua orang mati dalam persekutuan dengan Adam (1 Kor. 15:22), terutama menunjuk kepada kematian jasmaniah.

Dalam sejarah pemeliharaan Allah kepada umat-Nya Allah telah mempresentasikan cara, metode dan prinsip-prinsip penggembalaan. Yehezkiel 34:16 mendeskripsikan prinsip-prinsip penggembalaan yang Allah lakukan yaitu mencari yang hilang, membawa pulang yang tersesat, membalut yang luka, menguatkan yang sakit serta melindungi yang gemuk dan yang kuat. Hal yang serupa harusnya dilakukan oleh gembala-gembala zaman sekarang. Orang-orang yang mengalami keterpurukan membutuhkan gembala-gembala yang perduli, yang memperhatikan serta membina mereka agar tidak larut dalam keterpurukan tersebut. 
Dalam Perjanjian baru Tuhan Yesus jugamelakukan pelayanan penggembalaan. Dalam Yohanes 4:1-26, Yesus melayani seorang perempuan Samaria yang hidup dalam perzinahan. Perempuan Samaria tersebut secara sosial terkucilkan dalam lingkungan masyarakatnya, serta dijauhi masyarakat setempat. Secara mental pasti ia juga merasa rendah diri dan merasa diri tidak layak bahkan ia tidak berani bergabung atau berkumpul dengan orang-orang yang ada di sekitarnya. Namun Tuhan Yesus justru datang dan duduk bersama perempuan samaria tersebut serta membuat ia merasa berharga, padahal ia menyadari bahwa sesungguhnya ia manusia yang sangat berdosa.

Walaupun Yesus mengasihi dan mendekati orang berdosa, la tidak tutup mata terhadap kesalahan yang mereka lakukan. Yesus mengasihi orang-orang berdosa, tetapi la membenci dosa. Begitulah seharusnya pergaulan gembala dengan orang yang melakukan pelanggaran. Justru yang berbuat salah yang harus didekati, dikunjungi, karena orang yang sakit memerlukan dokter lebih daripada yang sehat. Orang yang melakukan pelanggaran yangperlu didekati, ditolong dan digembalakan, tetapi tidak berarti bahwa gembala juga membenarkan perbuatan atau perkataan jahat orang yang berbuat salah, akan tetapi membawa mereka kepada pertobatan dan hidup yang baru.

\section{METODE PENELITIAN}

Penelitian ini adalah penelitian kualitatif dengan pendekatan grammatical analysis. grammatical analysis adalah "the first stage of determining the inner cohesion of the text is to analyze the relationships entween the individual units or terms in the next". (Osbone;1991:19). Paradigma yang digunakan adalah paradigma naturalistik, yang pada hakikatnya merupakan suatu upaya untuk menemukan kebenaran atau untuk lebih membenarkan kebenaran. Kebenaran yang dimaksud adalah Kebenaran konsep Integritas yang tertulis dalam Yehezkiel 34:16.

Teknik pengumpulan data dalam penelitian ini dilakukan dengan pengamatan atau partisipasi langsung dan penelaahan dokumen.

Analisis data yang digunakan dalam penelitian ini mengikuti langkah-langkah grammatical analysis. Langkah penafsiran yang akan ditempuh sebagai berikut: 1). Teks Yehezkiel 34:16 akan ditafsirkan; 2). Penafsiran pada ayat ini akan mengerucut kepada kalimat demi kalimat dan frasa demi frasa; 3). Penelusuran terhadap meaning dari setiap frasa akan sangat terlihat hal ini dengan Tujuan supaya dapat melihat atau mendapat sense dari meaning yang dimaksud berkenaan dengan pastoral konseling sebagai upaya pemuliha iman.

\section{Hasil Dan Pembahasan}

\section{Pastoral Konseling Menurut Yehezkiel 34:16}

Dalam bab ini penulis akan menguraikan beberapa hal yakni, definisi pastoral konseling, fungsi pastoral konseling, tujuan pastoral konseling, informasi umum kitab Yehezkiel, serta inti berita kitab Yehezkiel.

\section{Definisi Pastoral Konseling}

Kata 'pastoral' berasal dari bahasa Latin 'pastor' yang artinya seorang yang bersifat seperti gembala yang bersedia merawat, memelihara, melindungi dan menolong orang lain. Sedangkan menurut Maria Bons-Storm dalam bukunya yang berjudul "Apakah Pengembalaan Itu?" menjelaskan bahwa: kata "gembala" dalam 
bahasa Latin ialah "pastor", dan dalam bahasa Yunani adalah "poimen" (в ). Oleh sebab itu pengembalaan dapat disebutkan dengan poimedika atau pastoralia. Kata gembala dipakai dalam Alkitab untuk menggambarkan tugas seorang hamba Tuhan untuk memelihara dan membimbing umat Tuhan sebagai kawanan domba Allah (1 Sam. 16:11; Mzm. 23; Yoh. 10:11; 21:15, 16, 18).

Kata konseling diartikan membimbing, mendampingi, menuntun, dan mengarahkan. Jadi konseling adalah pelayanan yang menolong seseorang yang dilakukan dalam bentuk komunikasi. Dalam percakapan tersebut terjadi interaksi dan komunikasi timbal-balik yang mendalam antara konselor dan konseli. Menurut Kamus Besar Bahasa Indonesia istilah konseling adalah pemberian nasehat atau arahan yang dilakukan oleh ahli kepada orang yang membutuhkan advice atas suatu masalah; penasehatan, pengarahan. Secara sederhana pengertian konseling dapat dinyatakan sebagai usaha untuk memberikan nasehat dan semangat. Walaupun sebenarnya konseling memiliki arti yang lebih luas lagi, yaitu merupakan proses untuk pertumbuhan dan perkembangan pribadi. Jadi, perlu ditekankan bahwa konseling tidak hanya dimaksudkan yang berkaitan dengan masalah-masalah hidup saja, tetapi juga bimbingan-bimbingan untuk melanjutkan kehidupan yang lebih baik.

Dari pengertian mengenai konseling yang telah dikemukakan diatas, maka penulis menarik kesimpulan bahwa pastoral konseling merupakan usaha konselor menolong konseli dengan cara memberikan nasehat dan pengertian kepada konseli mengenai masalah yang dialami. Dengan demikian konseli dapat memahami masalah hidupnya dalam terang firman Allah dan mengambil keputusan yang bijaksana untuk menyelesaikan masalahnya.

\section{Fungsi Pastoral Konseling \\ Menyembuhkan Manusia Seutuhnya (Healing)}

Pastoral konseling berfungsi untuk menyembuhkan manusia seutuhnya. Menurut kesaksian Alkitab, manusia adalah manusia yang utuh, yang terdiri dari tubuh dan jiwa. Keutuhan manusia juga terjadi ketika hidup bersama dengan orang lain, menjalin hubungan atau relasi dalam suatu konteks politik, sosial dan suatu kebudayaan tertentu. Dalam hal pendampingan pastoral, fungsi menyembuhkan ini penting dalam arti bahwa melalui pendampingan yang berisi kasih sayang, rela mendengarkan segala keluhan batin, dan kepedulian yang tinggi akan membuat seseorang yang sedang tertekan mengalami rasa aman dan kelegaan sebagai pintu masuk ke arah penyembuhan yang sebenarnya. Selain relasi dengan sesama terpulihkan, manusia terlebih harus mengutamakan relasinya dengan Tuhan mengalami pemulihan. Menyembuhkan manusia seutuhnya berbicara mengenai pemulihan manusia secara totalitas dan hal ini membutuhkan proses yang panjang untuk dilakukan seorang konselor.

\section{Menopang (Shore up)}

Seringkali konselor diperhadapkan kepada seseorang yang tiba-tiba mengalami krisis mendalam dan seringkali juga pada saat itu konselor tidak dapat berbuat banyak untuk menolong. Keadaan ini bukan berarti konselor tidak dapat melakukan pendampingan.Tetapi kehadiran konselor adalah untuk membantu seseorang bertahan dalam situasi krisis berat. Sokongan berupa kehadiran dan sapaan yang meneduhkan dan sikap terbuka akan mengurangi penderitaan seseorang. Jadi 
kehadiran seorang konselor sangat berarti bagi setiap konseli untuk dapat memberi dukungan berupa motivasi bagi konseli agar konseli dapat bangkit dari keterpurukan yang sedang dialami.

\section{Mendamaikan (Reconciliation)}

Dalam pelayanan pastoral kita sering bertemu dengan orang-orang yang hidup terpisah atau terasing, baik dari orang-orang yang ada disekitarnya, maupun persekutuan mereka dengan Allah.Menurut pendapat para ahli fungsi mendamaikan ialah, berusaha memperbaiki relasi yang rusak antara manusia dan sesamanya manusia, serta manusia dengan Allah. Jadi pastoral konseling juga berfungsi untuk menolong dan mendamaikan serta memperbaiki hubungan manusia dengan sesama, maupun hubungannya dengan Tuhan.

\section{Prinsip-Prinsip Pastoral Konseling Menurut Yehezkiel 34:16}

Adapun prinsip-prinsip pastoral konseling menurut Yehezkiel 34:16 sebagai upaya pemulihan mental adalah sebagai berikut:

\section{Mencari yang Bergumul}

Konseling pastoral adalah sebuah proses pelayanan untuk menolong konseli, sebaliknya konselor adalah pihak yang memberi pertolongan. Konseli yang sebagai orang yang ditolong tidak mampu melihat persoalannya dengan jernih. Orang yang bergumul dengan berbagai macam problem memerlukan pertolongan dari orang lain. Tugas seorang gembala adalah mencari domba yang sedang bergumul atau yang sedang membutuhkan pertolongan dan topangan.

Frasa "yang hilang Akan Kucari" memakai kata (et- haobedet) dari kata dasar (abad). Kata ini memakai kata penghubung tae (et) yang artinya itu dan menggunakan awalan penentu_ (ha) particle direct object marker homonym 1 serta ini menunjukkan kepada objek yang hilang yaitu domba, dimana domba yang dimaksud di sini adalah bangsa Israel. Kata "hilang" ditulis dengan menggunakan kata the lost(hilang). Kata (abad) ditulis dalam bentuk verb qal participle feminine singular. Verb qal ialah kata kerja aktif biasa, partisiple adalah suatu pekerjaan yang sedang berlangsung, sedangkan feminine singular menunjuk kepada bangsa Israel. Jadi kata "yang hilang" yang dimaksud menunjuk pada domba yaitu bangsa Israel yang sedang dalam keadaan kebingungan atau ke hilangan arah.

Dalam TWOT kata "yang hilang" diartikan dengan kata perish (tewas), be destroyed (dihancurkan), dan ditulis dalam bentukkata kerja piel dan hiphil. Arti dari kata perish, dan be destroyed ini ditulis dalam bentuk kata kerja piel dan hiphil yang merupakan suatu kata yang berfungsi sebagai pelengkap yang memiliki arti terbunuh dan pecah (kill, dan break down). Hal ini sama dengan kebinasaan yang akan dialami oleh Mesir (Kel. 10: 7), dan sama juga seperti pada waktu Yosua memberi peringatan kepada bangsa Israel tentang dosa-dosa mereka, ketika Israel tidak taat maka Tuhan akan menghancurkan mereka (bdk. Yos. 23: 16). Itu artinya kata ini mau menjelaskan bahwa yang hilang itu adalah domba yang menunjuk kepada bangsa Israel. Pada waktu itu keadaan bangsa Israel sangat memprihatinkan, mereka bukan hanya sekedar hilang mereka hancur, tewas, terbunuh, dan pecah serta terserak.

Frasa "akan Kucari" dalam bahasa Ibraninya (abaqesh) dari kata dasar (baqash), yang artinya I will seek (Aku akan mencari) yang ditulis dalam bentuk Piel Imperfect 1person common singular. Piel artinya menyatakan suatu tindakan yang lebih 
tegas dan dilakukan secara berulang-ulang, sungguh-sungguh, imperfect 1 person common singular merupakan pekerjaan yang masih akan dikerjakan oleh orang pertama tunggal (TUHAN). R. Laird dalam TWOTmemberi pengertian yaitu: to seek (mencari, mencoba), require (memerlukan), desire (kehendak, keinginan, dan rindu), to seek to find (mencari sampai dapat). France Brown dalam BDB menjelaskan secara khusus arti Baqash yaitu: Seek to secure yang artinya mencari untuk melindungi.

Jadi kata "akan Kucari" menunjukkan kerinduan atau keinginan Allah untuk mencari bangsa Israel (domba-domba-Nya) yang sedang tersesat dengan cara menolong mereka dari gembala-gembala yang tidak melakukan tugas dan tanggungjawabnya dengan benar. Kata ini memiliki bentuk piel yang bukan hanya sebatas kerinduan saja namun lebih tegas lagi dengan cara Allah turun tangan sendiri untuk mencari umat-Nya yang hilang dan tercerai-berai. Bahkan bukan hanya sekedar mencari saja namun berusaha sekuat tenaga untuk menemukannya kembali dan mengumpulkan mereka menjadi satu kembali serta melindungi mereka dari tangan yang tidak bertanggungjawab. Allah melihat tidak ada lagi gembala yang melakukan fungsi dan tugasnya dengan benar pada waktu itu, sehingga Allah akhirnya mengambil alih tugas dan tanggungjawab para pemimpin Israel.

Dalam nubuat ini Allah melawan gembala-gembala yang fasik (penguasa). Karena para gembala pada masa lalu telah gagal dalam memikul tanggung jawab atas dombadomba (ay. 2-6), Allah sendiri yang datang melawan mereka dan menyelamatkan domba-domba. Allah akan mengambil alih tanggung jawab para gembala (ay. 11-16). Allah akan menjadi gembala yang baik (bdk. Kej.48:15; Mzm. 23). Tuhan sendiri yang akan memperhatikan domba-domba, mengumpulkan mereka yang tercerai-berai, serta membimbing mereka ke padang rumput hijau di tanah air mereka, di mana yang hilang tersebut akan di cari Allah.

Jadi, kata "yang hilang akan kucari" ini menunjukan bahwa Allah akan selalu memperhatikan umat-Nya yaitu bangsa Israel yang diibaratkan sebagai domba-domba yang sedang tersesat dan tercerai-berai yang tidak tahu kemana mereka melangkah. Tuhan sebagai gembala yang baik dan bertanggungjawab menuntun, membimbing dan melindungi mereka dari gembala-gembala yang fasik dan tidak bertanggungjawab dan yang membuat mereka semakin hilang dari Allah.

\section{Membimbing Konseli Datang kepada Tuhan}

Pelayanan pastoral atau pengembalaan adalah suatu proses yang panjang. Proses ini dapat kita umpamakan dengan suatu jalan yang harus ditempuh oleh konseli yang kita layani. Oleh karena itu konseli tidak dapat menempuhnya seorang diri, ia membutuhkan orang lain atau konselor yang dapat menuntun dan membimbingnya.

Frasa "yang tersesat" dalam bahasa Ibrani_ (weet-nadahat) ditulis dalam bentuk ? (we) particle conjunction (kata penghubung, artinya dan) $\mathbf{N}$ (et) particle direct object marker homonym 1, (artinya dengan), ה (ha) particle article (artinya itu) $\pi$ (nadah) verb niphal participle feminine singular absolute homonym 1 yang berarti, kata kerja pasif yang menunjuk pada orang pertama yaitu bangsa Israel sepenuhnya. Dalam bahasa inggris kata "yang tersesat" ditulis,impel, drive away(menghalau). Dalam TWOT, kata "yang tersesat" artinya mencerai-beraikan, menyesatkan, dicerai-beraikan, tersesat, disesatkan, mengayunkan, berserak-serak. Sedangkan dalam NAS menterjemahkan the scattered artinya yang terserak. 
Jadi, kata "yang tersesat" ini mengarah kepada bangsa Israel yang pada waktu itu disesatkan, dicerai-beraikan dan berserak-serak. Pada waktu itu para pemimpinatau gembala tidak menuntun mereka kepada Tuhan melainkan membiarkan mereka melakukan penyembahan berhala serta membiarkan mereka berjalan sendiri.Sehingga hal itu mengakibatkan domba-domba tersebut tercerai berai, tersesat, dan jauh dari pada Allah.Bahkan bangsa Israel dikatakanmenjadi makanan binatang dihutan, hal inilah yangpada akhirnya mendukakan hati Allah (Yeh. 34:5).Oleh sebab itu Allah mengutus Yehezkiel untuk bernubuat untuk menentang para gembala (pemimpin) Israel, yaitu para raja, imam dan nabi pada waktu itu.

Oleh karena keserakahan, korupsi, dan mementingkan diri sendiri, membuat para pemimpin Israel lalai menuntun umat Allah sebagaimana yang dikehendaki olehNya.Para pemimpin memeras umat itu (Yeh. 34:3) dan menggunakan mereka untuk kepentingan pribadi dan bukan menolong mereka secara rohani yang sedang dalam kesesatan (Yeh. 34:4). Oleh karena Tuhan sangat mengasihi umat-Nya, maka Allah sendiri berjanji demi dirinya sendiri untuk membawa mereka kembali kepada-Nya dari kesesatan mereka karena perlakuan gembala-gembala (para pemimpin, nabidan imam) Tuhan berjanji "yang tersesat akan Kubawa pulang".

Frasa "akan Kubawa pulang" dalam bahasa Ibrani s (asib) dari kata dasar (shûb) ditulis dalam bentuk verb hiphil imperfect 1st person common singular, yang berarti kata kerja sebab akibat yang menyatakan keakanan oleh orang pertama tunggal, yaitu Allah sendiri. Dalam bahasa Inggris diartikan return (kembali). Dalam King James Version menterjemahkan and bring again artinya (dan membawa lagi), dan NAS menterjemahkan and bring back, artinya (dan membawa kembali) sedangkan dalam TWOT menerjemahkan memulihkan. Dalam hal ini "akan Kubawa pulang" disini, mengarah kepada janji Allah kepada bangsa Israel yang akan membawa mereka pulang (kembali) kepada Tuhan.

Jadi kata"yang tersesat akan Kubawa pulang" berarti, Allah sendiri yang akan menggembalakan mereka dan membiarkan mereka berbaring (ay. 15), dan Allah akan membawa mereka kembali kepada-Nya serta menggembalakan mereka sebagaimana yang seharusnya dilakukan oleh seorang gembala kepada domba-dombanya. Allah juga berjanji akan memulihkan mereka agar mereka kembali dari kesesatan dan ketidaktahuan mereka untuk datang memuji Tuhan dan hidup dalam pimpinan Allah.

\section{Memulihkan dari Luka Batin}

Luka batin dan luka fisik memiliki persamaan dan perbedaan. Persamaannya keduanya terasa menyakitkan, meninggalkan bekas, perlu dibersihkan, dan disembuhkan selama beberapa waktu. Sedangkan perbedaannya luka batin tidak terlihat secara langsung dari luar sedangkan luka fisik terlihat secara langsung dari luar. Beberapa orang yang mengalami luka batin tidak dapat mengingat sebagian atau seluruh pengalaman mereka. Mereka kehilangan kepekaan, tidak begitu peduli dengan dirinya sendiri, dan seolah kehilangan tenaga. Akan tetapi, ada juga beberapa dari mereka yang terus-menerus memikirkan peristiwa buruk yang telah mereka alami.

Semua tindakan yang dilakukan oleh para gembala pada waktu itu terhadap umat Israel tidaklah disukai oleh Allah. Para gembala tidak memberi perhatiannya kepada domba-domba (Israel), terbukti pada ayat 4 dikatakan bahwa para gembala membiarkan domba-domba tersebut. Hal ini membuat Allah murka sehingga Allah sendiri berniat untuk memulihkan kembali umat Israel dengan cara Allah sendiri. Dapat 
dilihat dalam ayat 16, Allah berfirman bahwa "Yang luka akan Kubalut". Kalimat ini

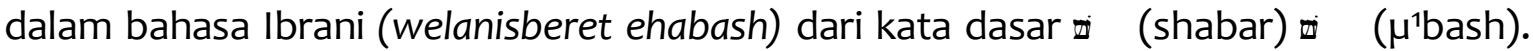
Kata "yang luka" (welanisberet) yang artinya and the crippled (yang pincang) ditulis dalam bentuk kata kerja! particle conjunctionl. particle prepositionh; particle article rbv verb niphal participle feminine singular absolute homonym 1. Particle conjunction merupakan kata penghubung yang artinya dan, particle prepositionmerupakan kata depan yang berarti untuk, dan particle article memiliki fungsi sebagai awalan penentu. Verb niphal merupakan kata kerja yang memiliki arti pasif dari qal, sedangkan feminine singular menunjuk kepada bangsa Israel, dan yang melakukan pekerjaan ini adalah Allah sendiri.

Jadi bangsa Israel sebagai orang yang terluka pasif tetapi Allah sendiri yang bekerja untuk membalut luka mereka. Hal ini menunjukkan bahwa pekerjaan yang Allah lakukan tidak ada campur tangan dari bangsa Israel atau orang lain, namun inisiatif dari Allah sendiri karena Allah sangat mengasihi umat pilihan-Nya.

Dalam BDB kata "yang luka" menggunakan kata wait (menantikan, menunggu) dan hope (berharap, mengharapkan). Hal ini menggambarkan kondisi bangsa Israel "yang luka" itu seperti orang yang menunggu, menantikan sesuatu, mengharapkan, dan berharap. Dalam TWOT menggunakan kata break in pieces (yang telah patah sampai terpotong-potong), dan hurt (luka hati). TWOT menjelaskan bahwa bangsa Israel ibarat suatu benda yang sudah patah sampai terpotong-potong, dan juga digambarkan seperti orang yang hatinya terluka. Dalam Analytical kata "yang luka" ditulis dengan kata and the crippled (yang pincang), "yang luka" melukiskan Israel seperti orang yang pincang. Ayat ini menunjukkan bahwa domba-domba (Israel) sedang membutuhkan pertolongan, karena saat itu keadaan mereka yang sedang pincang dan tidak dapat berjalan sendiri.

Allah mengasihi bangsa Israel karena bangsa Israel adalah umat pilihan Allah, maka dari itu Allah sendiri yang akan menjadi gembala bagi mereka. Allah yang akan membalut mereka dari "luka", dan Allah yang akan "membalutnya". Kata "akan Kubalut" dalam bahasa ibraninya (ehabosh) ditulis dalam bentuk verb qal imperfect 1st person common singular, artinya kata kerja aktif biasa yang belum sempurna atau masih akan dilakukan oleh orang pertama tunggal yaitu Allah. "Akan Kubalut" dalam Analitycal memiliki arti I will bind up (Aku akan ikat). Dalam TWOT kata ini menggunakan bind (menambat, menjilid), bandage (memperban), restrain (menahan, mengendalikan). Dalam hal ini Allah sendiri yang akan menambat, menjilid (seperti menyatukan lembaran kertas dan menjadikannya tersusun rapi), memperban, menahan, mengendalikan (mengontrol) bangsa Israel.

Ungkapan "yang luka akan Kubalut" dalam teks ini memiliki arti bahwa bangsa Israel yang sedang berharap, menanti, yang hatinya terluka, dan digambarkan seperti orang pincang, yang patah sampai terpotong-potong (gambaran Israel yang terceraiberai). Allah sendiri yang akan membalut mereka, memperban (mengobati dengan cara membungkus), mengendalikan Israel dari ketidakseimbangannya (seperti orang pincang) serta Allah juga yang akan memenuhi harapan bangsa Israel.

\section{Memberi Motivasi}

Dalam Kamus Besar Bahasa Indonesia "motivasi" adalah dorongan yang timbul pada diri seseorang secara sadar atau tidak sadar untuk melakukan suatu tindakan dengan tujuan tertentu atau usaha yang dapat menyebabkan seseorang atau 
sekelompok orang tertentu tergerak melakukan sesuatu karena ingin mencapai tujuan yang dikehendakinya atau mendapat kepuasan dengan perbuatannya. Jadi memberi motivasi berarti melakukan suatu tindakan yang dapat mendorong seseorang untuk mencapai tujuan yang hendak dicapainya.

Dalam teks ini, bangsa Israel dikatakan "hilang, mereka tersesat, luka," dan mereka pun "sakit". Kata sakit dalam KBBI diartikan dengan, berasa tidak nyaman di tubuh atau bagian tubuh karena menderita sesuatu. Istilah "yang sakit" dalam terjemahan lain adalah sickness (penyakit), disease (penyakit), to become sickness or faint (menjadi sakit, pingsan, redam, redup, menjadi sedikit). Sedangkan dalam BDB menterjemahkan infirmity (kelemahan), grieve (berdukacita, bersedih hati), stroke (terpukul, serangan otak), entreat (meminta/memohon dengan sangat), Grief (mendapat kesulitan, gagal, mengalami kegagalan). Artinya bahwa penyakit yang mereka alami bukan hanya penyakit biasa misalnya demam karena flu dan batuk, tetapi penyakit mereka lebih dari itu.Umat Israel mengalami berbagai penderitaan batin dan sangat mengganggu jiwa, akibatnya kelemahan yang ada menguasai diri mereka sehingga akhirnya mereka gagal dan sulit untuk maju.Sekalipun mereka memohon dengan sangat tetapi semangat mereka untuk maju telah menjadi redup, karena tidak ada yang mempedulikan mereka.

Istilah "yang sakit" dalam teks ini ditulis dengan? (we) particle conjunction tae particle direct object marker homonym1_ (ha) particle article is (halah) verb qal participle feminine singular absolute. Particle conjunction adalah kata penghubung dengan pengertian "yang". Particle article memiliki fungsi sebagai awalan penentu, dan (et) particle direct object marker homonym1 menunjuk kepada objek yang sakit (domba) yaitu bangsa Israel. Sedangkan kata $\pi$ (halah) verb qal participle feminine singular absolute artinya adalah kata kerja aktif biasa yang sedang berlangsung atau terus-menerus yang ditujukan kepada bangsa Israel.

Berdasarkan pengertian di atas dapat disimpulkan bahwa umat Israel sedang sakit.Penyakit tersebut tidak hanya menggangu mereka secara jasmani namun juga secara rohani.Sakit yang bangsa Israel alami yaitu kedukaan dan kesedihan hati sehingga mereka terlihat seperti orang yang sedang pingsan.Keadaan mereka diibaratkan seperti lampu yang nyalanya sudah tidak memberikan cahaya yang sempurna, tetapi memancarkan sinar yang redup (hampir mati). Bahkan lebih dari itu, sakit yang bangsa Israel alami sampai menyerang otak, sehingga membuat mereka tidak dapat melakukan sesuatu yang berfaedah untuk diri mereka sendiri terlebih lagi untuk Tuhan.

Oleh sebab itu, dalam pernyataan berikutnya Tuhan mengatakan "Ku-kuatkan", artinya bahwa yang sakit akan dikuatkan oleh Tuhan. Hal ini terbukti dari pernyataan Tuhan. Kata "Kukuatkan" ditulis dalam bentuk kata $¥$, (hazaq) verb piel imperfect 1st person common singular. Artinya menyatakan suatu tindakan yang lebih tegas dan dilakukan secara berulang-ulang dengan sungguh-sungguh oleh orang pertama tunggal (TUHAN), tetapi pekerjaan ini masih akan dilakukan oleh TUHAN.

Pengertian lain dari istilah "Kukuatkan" adalah be come (mendatangi), strong (kuat), strength (kekuatan, tenaga), strengthen (memperkuat), prevail (membujuk), harden (mengeraskan, memperkeras), be courageous (memberikan keberanian). Dalam BDB cure (perawatan, pengobatan, menyembuhkan penyakitnya, mengawetkan), help (menolong, membantu, menuntun), repair (memperbaiki, mereparasi, membetulkan), fortify (membangun, membentengi), to bind (membalut), 
restrain (mengendalikan, menahan), cleave (memegang erat-erat), established (mendirikan, menetapkan), to lean (menyandarkan), recovered (menyembuhkan), take (membawa, menerima, melakukan). Withstand (menahan, bertahan). Dengan demikian dapat disimpulkan bahwa Tuhan bukan hanya sekedar mendatangi mereka, tetapi Tuhan juga akan menolong, memperkuat, menuntun serta memberikan keberanian kepada mereka.

Allah menyatakan kasih-Nya dengan tindakan sungguh-sungguh yaitu Tuhan mendatangi mereka, lalu memberikan perawatan intensif untuk menyembuhkan sakit yang sedang bangsa Israel alami.Ketika bangsa Israel lemah Tuhan datang memberikan pertolongan dengan menahan, memegang mereka erat-erat, dan menuntun supaya mereka tetap berdiri.Bahkan Tuhan rela untuk menjadi tempat bersandar bagi umat Israel yang sedang sakit.Segala yang telah rusak dalam diri umatNya di perbaiki dan dibetulkan.Tuhan sangat mengasihi dan perduli kepada bangsa Israel yang tidak diperhatikan oleh para pemimpinnya, sehingga Tuhan membentengi mereka, supaya umat-Nya tetap bertahan dan terlindungi.

\section{Kesimpulan}

Berdasarkan penjelasan dari uraian di atas, penulis menyimpulkan bahwa penggembalaan sesungguhnya adalah suatu pelayanan dan pekerjaan yang sangat penting dan mendesak untuk dilakukan oleh seorang gembala, dalam hal ini adalah hamba Tuhan terhadap umat gembalaannya. Penggembalaan penting untuk dilakukan tentunya karena ada beberapa orang yang merasa terabaikan dalam kehidupannya dan merasa tidak diperdulikan oleh sesamanya. Hal inilah yang seharusnya mendorong seorang gembala untuk memperhatikan domba-dombanya yang sedang membutuhkan pertolongan.

Oleh sebab itu, dalam Yehezkiel 34:16 dengan tegas Allah menyatakan bahwa la sendiri sebagai gembala yang baik telah dan akan melakukan penggembalaan itu kepada domba-domba-Nya yaitu umat Israel. Allah melalui inisiatif-Nya sendiri akan mencari setiap orang yang hilang, membalut mereka yang terluka, membawa pulang yang tersesat, menguatkan yang sakit, serta melindungi yang kuat dan yang gemuk. Ini menunjukkan bahwa Allah telah melakukan tugas dan tanggungjawabnya sebagai seorang gembala dengan baik. Seorang gembala yang baik tidak mungkin mengabaikan atau tidak memperdulikan pergumulan yang dihadapi oleh umat gembalaannya.Dengan demikian penggembalaan adalah sesuatu yang sangat penting untuk dilakukan kepada setiap orang yang sedang mengalami masalah, karena melalui pelayanaan penggembalaan orang-orang yang sedang mengalami tekanan hidup tersebut dapat mengalami pemulihan.Hal inilah yang membuat Allah menegur setiap gembala yang mulai mengabaikan domba-domba gembalaannya, karena Allah tidak menghendaki jika umat pilihan-Nya tercerai-berai dari kawanan domba lainnya.

Pelayanan penggembalaan berfungsi untuk membawa pemulihan bagi setiap orang yang sedang bergumul. Seorang gembala yang baik harus memiliki kepekaan dan inisiatif sendiri tanpa paksaan untuk melayani domba-domba yang telah Allah percayakan untuk digembalakan. Tugas seorang gembala adalah menuntun, membimbing, melindungi serta memelihara domba-dombanya. Agar tidak ada satupun dari antara domba-domba itu yang hilang ataupun tersesat bahkan mati. Domba butuh penuntun, karena tanpa penuntun domba akan kehilangan arah bahkan bisa sampai tersesat dan tercerai-berai. 
Seorang gembala yang baik harusnya lebih mengutamakan fungsinya daripada jabatannya, karena tanpa realisasi nyata dari tugas tanggung jawab yang diembannya seseorang tidak dapat dikatakan sebagai gembala yang baik. Seorang gembala yang baik akan selalu memiliki kepekaan yang tinggi akan kebutuhan domba yang dipercayakan kepadanya. Sehingga dengan demikian pelayanan penggembalaan yang dilakukan akan memberikan motivasi dan semangat karena dapat menolong dan mengangkat orang-orang yang sedang membutuhkan pertolongan. Oleh karena itu gembala dituntut harus memiliki kepekaan terhadap keadaan yang sedang dialami oleh setiap domba-dombanya. Karena gembala yang baik pasti mengenal dan mengetahui kebutuhan domba gembalaannya. 


\section{Kepustakaan}

Abineno, J. L. Ch.

2011

Pedoman Praktis Untuk Pelayanan Pastoral, Jakarta: BPK Gunung Mulia,

Atkinson, David

1996 Kejadian 1-11, Jakarta: Yayasan Komunikasi Bina Kasih,

Brown, France

1979 The New Brown Driver Bridge Genesius Hebrew and English Lexicon, Publisher: Messa Chutes Hendriason

Bergant, Dianne dan Robert J. Karris, 2002 Tafsir Alkitab Perjanjian Lama, Yogyakarta: Kanisius,

Boeker, T. G. R. 1987 Bahasa Ibrani Jilid II Batu: Institut Injili Indonesia,

Beek, Aart Van $2001 \quad$ Pendampingan Pastoral, Jakarta: BPK Gunung Mulia, Beek, Aart Martin Van

1992 Konseling Pastoral, Semarang: Satya Wacana,

Douglas, J. D

1995

Ensiklopedi Alkitab Masa Kini Jilid 2, Jakarta: Yayasan Komunikasi Bina Kasih,

Indra, Ichwei G.

2010 Teologi Sistematis, Bandung: Lembaga Literatur Baptis,

Gintings, E. P.

2009 Konseling Pastoral, Jabar: Bina Media Informasi,

Barth, Marie Claire dan B. A. Pareira,

1999 Tafsiran Alkitab Kitab Mazmur1-72, Jakarta: BPK Gunung Mulia,

Thiessen, Henry C.

1992 Teologi Sistematika, Malang: Gandum Mas,

Storm, M. Bons

1998 Apakah Pengembalaan Itu?, Jakarta: BPK Gunung Mulia,

Tu'u, Tulus

2007 Dasar-Dasar Konseling Pastoral, Yogyakarta: ANDI,

Pena, Tim Prima

$2000 \quad$ Kamus Besar Bahasa Indonesia, Jakarta: Gramedia Press,

Tanuwijaya, Stephen

2004 Bimbingan Konselor Kristen, Jakarta: STTI Philadelphia,

Haris, R. Laird

1981

Theological Word Book Of The Old Testament, Chichago: Moody Press, 